
\title{
3 Research Square \\ Complete Genome Sequence of Unusual Strain of Zika Virus From West Africa
}

\section{Research Article}

Keywords:

Posted Date: September 9th, 2022

DOI: https://doi.org/10.21203/rs.3.rs-1203528/v2

License: (c) (1) This work is licensed under a Creative Commons Attribution 4.0 International License. Read Full License

\section{EDITORIAL NOTE:}

Research Square has withdrawn this preprint. Please do not cite this preprint as it contains ethical issues with infringement of the author list and conflict of interest. 


\section{Abstract}

The full text of this preprint has been withdrawn by Resarch Square. Please do not cite this preprint as it contains ethical issues with infringement of the author list and conflict of interest.

\section{Full Text}

The full text of this preprint has been withdrawn by Resarch Square. Please do not cite this preprint as it contains ethical issues with infringement of the author list and conflict of interest. 